\title{
A Simple and Rapid Leaf Genomic DNA Extraction Method for Pearl Millet (Pennisetum glaucum L. R. Br)
}

Ogechi Nweke (Corresponding author)

Biotechnology and Genetic Engineering Advanced Laboratory, Sheda Science and Technology Complex, PMB 186, Garki, Abuja, Nigeria Tel: 234-806-126-1078Ｅ-mail: ogechi3ng@yahoo.com

\section{Charles Osuji}

Biotechnology and Genetic Engineering Advanced Laboratory,

Sheda Science and Technology Complex, PMB 186, Garki, Abuja, Nigeria

Tel: 234-803-690-4820Ｅ-mail: charleschuks@gmail.com

Abolade S. Afolabi

Biotechnology and Genetic Engineering Advanced Laboratory,

Sheda Science and Technology Complex, PMB 186, Garki, Abuja, Nigeria

Tel: 234-803-488-1092 E-mail: abolade.afolabi.wagner.edu

Inuwa H. Mairo

Department of Biochemistry,

Ahmadu Bello University, Zaria, Kaduna State, Nigeria

E-mail: inuwahm@yahoo.com 
Paul C. Onyenekwe

Biotechnology and Genetic Engineering Advanced Laboratory,

Sheda Science and Technology Complex, PMB 186, Garki, Abuja, Nigeria

Tel: 234-803-634-7293Ｅ-mail: pconyenekwe@yahoo.com

Received: April 12, 2014 Accepted: July 23, 2014 Published: July 25, 2014

Doi: 10.5296/jab.v2i2.5440 URL: http://dx.doi.org/10.5296/jab.v2i2.5440

\begin{abstract}
Pearl millet is widely grown as a multi-purpose cereal grain crop for feed, fodder, fuel and mulch predominantly in the semi-arid tropics. It is highly adapted to drought, representing an essential component of the food security and livelihood of many million poor farmers. DNA extraction is unusually difficult in some plants due to the presence of secondary metabolites that interfere with DNA isolation making it very laborious and time consuming. An effective genomic DNA extraction should be simple, cost effective, with good yield and high purity. The protocol used in this study involved the extraction of genomic DNA from fresh leaves using the Sodium dodecyl sulphate (SDS) method with slight modifications including absence of use of liquid nitrogen which is difficult and expensive to obtain in the developing World. Genomic DNA obtained from the ten pearl millet samples using this procedure was good.
\end{abstract}

Keywords: Pennisetum glaucum, Genomic DNA extraction, Sodium Dodecyl Sulphate, Secondary metabolites, Fresh leaves 


\section{Introduction}

Pearl millet (Pennisetum glaucum L. R. Br.) which belongs to family poaceae (graminae), is a tall, warm season, annual grass widely grown for feed, fodder, fuel and mulch in more than 26 million hectares mostly in the semi-arid tropics of sub-Saharan Africa and India (FAO \& ICRISAT, 1996). It is the sixth most important coarse-grain cereal grown in these regions (Gari, 2002). Pearl millet also plays a critical role in food security, because it is has the highest levels of tolerance to heat and drought among tropical cereals (Khairwal et al., 2007),

Genomic DNA extraction is usually a prerequisite for molecular and forensic analysis. Different methods have been used in isolating genomic DNA, these methods include, the Cetyl Trimethyl Ammonium Bromide (CTAB) method and its modifications (Huang et al., 2000; Doyle et al., 1987), which is the most routinely used method, the Sarkosyl Nitrogen method, the Sodium dodecyl-sulfate (SDS) method, the Phenol/chloroform method and the

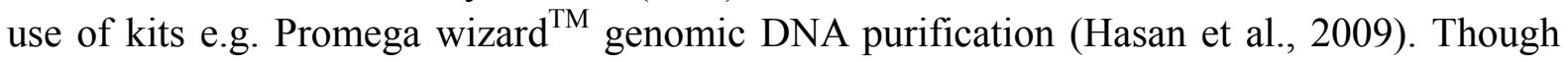
these methods have been widely used and successful in isolating DNA from different plant species, they are time consuming, laborious and not cost effective especially in resource limited laboratories. Some of these protocols include the use of liquid nitrogen and DNA isolation kits which is not easy to obtain due to high cost (Amani et al., 2011; Ahmed et al., 2009)

The presence of metabolites in plants has made genomic DNA extraction a difficult process. These secondary metabolites include alkaloids, flavonoids, phenolic compounds, gummy polysaccharides, terpenes and quinine are co-extracted with the DNA during isolation which makes purification difficult (Shepherd et al., 2002). For downstream applications such as DNA restriction, amplification, and cloning, "clean" DNA isolation is required. While the degree of purity and quantity of DNA is important, it varies between applications. A good extraction procedure for the isolation of DNA should yield adequate and intact DNA of reasonable purity. The procedure should also be quick, simple and cheap (Zidani et al., 2005). The aim of this study, therefore, was to determine a genomic DNA extraction protocol suited for isolation of reasonably pure DNA in sufficient amount from pearl millet fresh leaves which is simple and rapid, without the use of expensive chemicals and specific equipment.

\section{Materials and Methods}

\subsection{Plant Material}

Ten samples of Pearl millet (Pennisetum glaucum [L.] R. Br.) Seeds were collected from Lake Chad Research Institute (LCRI) Maiduguri, Nigeria, germinated and grown for 7 days. The tissues used were young fresh leaves.

\subsection{Solutions}

An extraction buffer consisting of 5\% SDS, 100mM Tris ( $\mathrm{pH} 8.0$ ), $50 \mathrm{mM}$ EDTA (pH 8.0), and $500 \mathrm{~m} \mathrm{M} \mathrm{NaCl}$, and $5 \mathrm{M}$ potassium acetate, was prepared. In addition, phenol-chloroform, isoamyl-alcohol (25:24:1), 70\% and 100\% ethanol and a TE buffer consisting of $10 \mathrm{mM}$ Tris (pH 8.0) and 1 mM EDTA (pH 8.0) were also prepared

\subsection{DNA Extraction Protocol}

$0.3 \mathrm{~g}$ of young fresh leaves were harvested and chopped into smaller pieces in a mortar. 800 
$\mu l$ of extraction buffer was added and without liquid nitrogen, round quickly, using a pestle to obtain a homogenous mixture. The homogenate was transferred into $1.5 \mathrm{ml}$ eppendorf tubes. $200 \mu \mathrm{l}$ of the extraction buffer was added again and mixed well by inversion. It was centrifuged at $4{ }^{\circ} \mathrm{C}$ for 2 minutes at $12,000 \mathrm{rpm}$. The supernatant was transferred into new eppendorf tubes. $200 \mu 1$ of $5 \mathrm{M}$ potassium acetate was added and mixed well. Equal volume of phenol-chloroform-isoamyl alcohol (25:24:1) was then added and mixed well by inversion. The tube was centrifuged at $4{ }^{\circ} \mathrm{C}$ for 5 minutes at $12,000 \mathrm{rpm}$.

The supernatant obtained was carefully transferred into a new eppendorf tubes without disturbing the interface. $800 \mu \mathrm{l}$ of absolute ethanol was added, mixed well by hand and kept on ice for 20 minutes. The tubes were removed from ice and centrifuged again at $4{ }^{\circ} \mathrm{C}$ for 5 minutes at 12,000rpm. The supernatant was discarded and the DNA pellet obtained was washed three times with $70 \%$ ethanol and air dried until the ethanol evaporated completely. The pellet was re-suspended in $100 \mu$ of TE buffer and 2 ul of RNase was then added. The tube was incubated at $37^{\circ} \mathrm{C}$ for $30 \mathrm{~min}$ (Ferdous et al., 2012)

\subsection{Amount and Purity of DNA}

The purity of DNA was determined by calculating the ratio of absorbance at $260 \mathrm{~nm}$ to that of $280 \mathrm{~nm}$ using a UV spectrophotometer (Eppendorf Biophotometer). The yield of DNA per gram of leaf tissue was also determined. Electrophoresis was carried out on DNA samples from the leaf tissues on a $0.8 \%$ agarose gel, according to Sambrook et al. (1989). Gels were stained with ethidium bromide and viewed and photographed using the gel documentation system (Alpha innotech).

\section{Result and Discussion}

The DNA extracted from ten varieties of pearl millet, were dissolved in $100 \mu 1$ of T.E. Each of the DNA samples optical density (OD) ratio $260 \mathrm{~nm} / 280 \mathrm{~nm}$ was calculated from the readings obtained from the readings at UV wavelength of $260 \mathrm{~nm}$ and $280 \mathrm{~nm}$ using a spectrophotometer (Bio photometer, Eppendorf). The values varied between 1.7 and 1. 9 (Figure 1).

DNA quality is considered good with an $\mathrm{OD}_{260}: \mathrm{OD}_{280}$ ratio between 1.7 and 2.0 (Maniatis et al., 1982, Gulia et al., 2010). Extracted DNA concentrations of the samples ranged between 1500 to $1700 \mathrm{ng}$ per extraction, which is sufficient for various downstream applications.

The quality of the extracted DNA was also evaluated using agarose gel electrophoresis. The sharp and distinct bands obtained after running on a $0.8 \%$ agarose gel, stained with ethidium bromide and visualized with UV light is shown in Figure 2.

Extraction of genomic DNA using this method was simple and easy, it was not time also consuming compared to other DNA extraction methods. The steps involved in isolation of DNA took approximately 30minutes.

This protocol also did not include the use of liquid nitrogen; the continuous supply of which is a problem in many resource limited laboratories in developing countries due to the cost and availability. Young fresh leaf tissues were used in this method, it was found that using younger leaves instead of older ones reduced nucleic acid contamination by plant metabolites that interfere with solubilisation of precipitated nucleic acids. A three-time wash combined with a short-run centrifugation was sufficient for DNA purification and removal of 
endogenous nucleases or other proteins. The purity of genomic DNA is dependent on the number of washes (Puchaa, 2004).

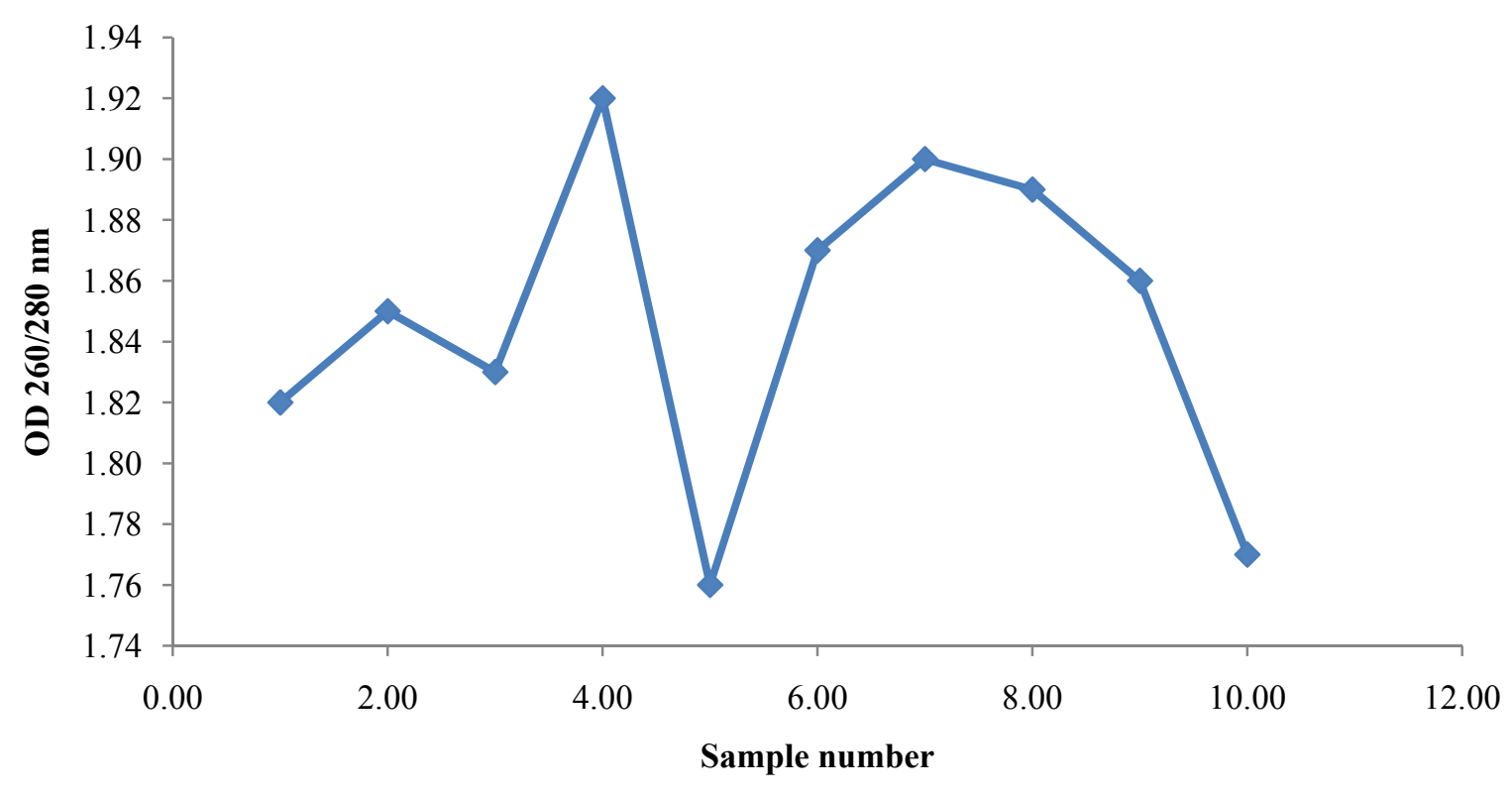

Figure 1. Optical density (OD) ratio of DNA samples extracted from the ten Pearl millet varieties

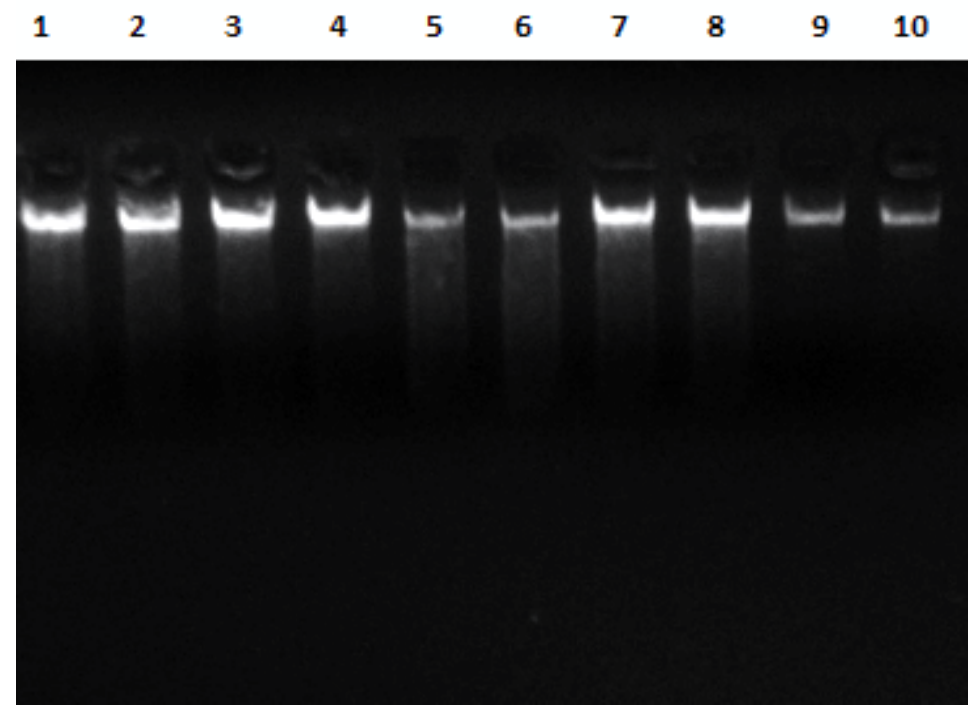

Figure 2. Bands obtained after agarose gel electrophoresis showing total DNA isolated from ten samples of Pearl millet (Pennisetum glaucum L. R. Br)

\section{Conclusion}

The efficiency, speed and the use of inexpensive facilities makes this protocol suitable for the extraction of DNA from leaf tissues of pearl millet and possibly other cereals. These results show that the DNA produced by this simple and rapid protocol can be used in PCR-based 
techniques and other applications

\section{Acknowledgments}

Thanks to my colleagues Salisu Abubakar and Vera Etim for their assistance.

\section{References}

Ahmed, I., Islam, M., Arshad, W., Mannan, A., Ahmad, W., \& Mirza1, B. (2009). High-quality plant DNA extraction for PCR: An easy approach. Journal of Applied Genetics, 50, 105-107. http://dx.doi.org/10.1007/BF03195661

Amani, A., Kazemi, R., Reza, A., Ali, H., \& Salmanian, A. (2011). A simple and rapid leaf genomic DNA extraction method for polymerase chain reaction analysis. Iranian Journal of Biotechnology, 9, 1.

Doyle, J. J., \& Doyle, J. L. (1987). A rapid DNA isolation procedure for small quantities of fresh leaf tissue. Phytochemical Bulletin, 19, 11-15.

FAO \& ICRISAT. (1996). The World Sorghum and Millet Economics. Facts, Trends and Outlook. Food and Agriculture of the United Nations. Via bledelle Termedi Caracalla, 00100 Rome, Italy. International Crops Research Institute for the Semi-Arid Tropics. Patancharu 502324, Andira, India.

Ferdous, J., Hanafi, M. M., Rafii, M. Y., \& Muhammad, K., (2012). A quick DNA extraction protocol: Without liquid nitrogen in ambient temperature. African Journal of Biotechnology, 11(27), 6956-6964.

Garí, A. J. (2002). Review of the African millet diversity. International Workshop on fonio, food security and livelihood among the rural poor in West Africapp. International Plant Genetic Resources Institute, Rome, Italy. pp. 1-18.

Sayed, M., Hasan, Z., Shafie, M., Shafie, B., \& Shah, R. M. (2009). Genomic DNA Extraction Methods from Wormwood Capillary (Artemisia capillaris) for PCR-RAPD Studies. New York Science Journal, 13-21.

Huang, J., Ge, X., \& Sun, M., (2000). Modified CTAB protocol using a silica matrix for isolation of plant genomic DNA. BioTechniques, 28, 432-434.

Khairwal, I. S., Rai, K. N., Diwakar, B., Sharma, Y. K., Rajpurohit, B. S., Nirwan, B., \& Bhattacharjee, R. (2007). Pearl millet: Crop management and seed production manual. Patancheru, Andhra Pradesh, India: ICRISAT. p. 108.

Maniatis, T., Fritsch, E. R., \& Sambrook, J. (1982). Quantification of DNA and RNA. In: Molecular Cloning: A Laboratory Manual. Cold Spring Harbor Laboratory Press: NewYork. pp. 448-469.

Puchooa, D. (2004). A simple, rapid and efficient method for the extraction of genomic DNA from lychee (Litchi chinensis Sonn.). African Journal of Biotechnology, 3, 253-255.

Sambrook, J. E., Feritsh, F., \& Maniatis, T. (1989). Molecular cloning- a laboratory manual (2nd ed.) New York Cold Spring Harbour.

Shepherd, M., Cross, M., Stokoe, L. R., Scott, L. J., \& Jones, M. E., (2002). High throughput DNA extraction from forest trees. Plant Molecular Biology. Reporter, 20, 425-425. http://dx.doi.org/10.1007/BF02772134 


\section{Macrothink}

Journal of Applied Biotechnology ISSN 2327-0640 2014, Vol. 2, No. 2

Zidani, S., Ferchichi, A., \& Chaieb, M., (2005). Genomic DNA extraction method from pearl millet (Pennisetum glaucum) leaves. African Journal of Biotechnology, 4, 862-866.

\section{Copyright Disclaimer}

Copyright reserved by the author(s).

This article is an open-access article distributed under the terms and conditions of the Creative Commons Attribution license (http://creativecommons.org/licenses/by/3.0/). 